\title{
DISTRIBUTION OF A UNIQUE LIMPET (GASTROPODA: ANCYLIDAE) IN THE COLORADO RIVER DRAINAGE BASIN, WESTERN NORTH AMERICA
}

\author{
Peter Hovingh 1
}

\begin{abstract}
I determined the distribution of limpets (Gastropoda: Ancylidae: Ferrissia) in the Colorado River and Rio Grande basins by handpicking specimens from the undersides of rocks and vegetation at 16 sites from a total of 495 surveyed sites in Colorado, Utah, New Mexico, and Arizona. Shell morphology, including morphometrics, was compared to species holotype descriptions and museum lots. Ferrissia rivularis occurred in the upper Colorado, Gunnison, and San Juan rivers, and in the upper Rio Grande basin. Ferrissia walkeri, hereafter called the Walker morph, occurred only in the Gila River basin of Arizona and New Mexico. I reviewed the problems of classification of the Walker morph as being either F. walkeri, described from Arkansas and noted in Michigan and Baja California Sur, or Ferrissia fragilis, described from California and noted from the eastern United States. The Walker morph is identified by its vertical trending protoconch, which lies well within the right posterior quadrant, with the apex of the shell within the posterior third, and the anterior edge of the protoconch lying posterior to and below the apex. The importance of the Gila River Ferrissia population is discussed in reference to the often-proposed paleoaquatic fauna route between the eastern United States and California.
\end{abstract}

Key words: Ancylidae, Gila River, Ferrissia walkeri, Ferrissia rivularis, Ferrissia fragilis, paleogeography, intermountain region.

Resumen.-Determiné la distribución de lapas (Ancylidae: Ferrissia) en las cuencas del Río Colorado y del Río Grande, recogiendo especímenes a mano de la superficie inferior de piedras y vegetación en 16 sitios entre un total de 495 sitios examinados en Colorado, Utah, Nuevo México y Arizona. Comparé la morfología de la concha, incluyendo la morfometría, con descripciones de holotipos de esta especie así como especímenes de museo. Identifiqué Ferrissia rivularis en el alto Río Colorado, Gunnison y Río San Juan, y en la cuenca del alto Río Grande. Ferrissia walkeri (de aquí en adelante llamada la forma morfológica Walker) sólo aparecía en la cuenca del Río Gila de Arizona y Nuevo México. Se resumen los problemas de clasificación del Walker morph como F. walkeri, descrito en Arkansas y observado en Michigan y Baja California del Sur, y como Ferrissia fragilis, descrito en California y observado en el oriente de los EE.UU. Se identifica la forma morfológica Walker por su protoconcha, doblada hacia el vertical, que se encuentra dentro del cuadrante derecho posterior, con el ápice de la concha dentro del tercio posterior, y el borde anterior de la protoconcha detrás y debajo del ápice. Hablamos sobre la importancia de las poblaciones de Ferrissia en el Río Gila en referencia a la ruta de fauna paleo-acuática entre el este de Estados Unidos y California.

Molluscan taxonomic criteria, such as shell shape, can appear arbitrary and simplistic, and museum collections and literature reports may not offer any consensus in this matter (Hovingh 2004). The lack of distributional studies presents a major barrier to species description and hinders the understanding of population variabilities and their vicariance evolution. Newton (2003, page 90) noted, "genealogy and distribution are not separate issues: they are simply different sides of the same biological coin."

In a previous report (Hovingh 2004), I showed that the intermountain Ferrissia rivularis (Say, 1817) had stream-specific distribution with similar shell shape, as measured by the parameters of length, width, height, and apex position in relation to distance from the posterior margin. An exception to these general observations was the Gila River Ferrissia in the San Pedro River and the shell specimens from Sabino Canyon, a Santa Cruz River tributary. This exception was confined to the parameter involving apex position, a characteristic that suggests Ferrissia walkeri Pilsbry and Ferriss, 1907, previously known only from Michigan, Arkansas, and Baja California Sur (Basch 1963, Burch 1989).

I have expanded the surveys of the Gila River and the adjacent upper Colorado, Little Colorado, San Juan, Gunnison, and Virgin rivers and 


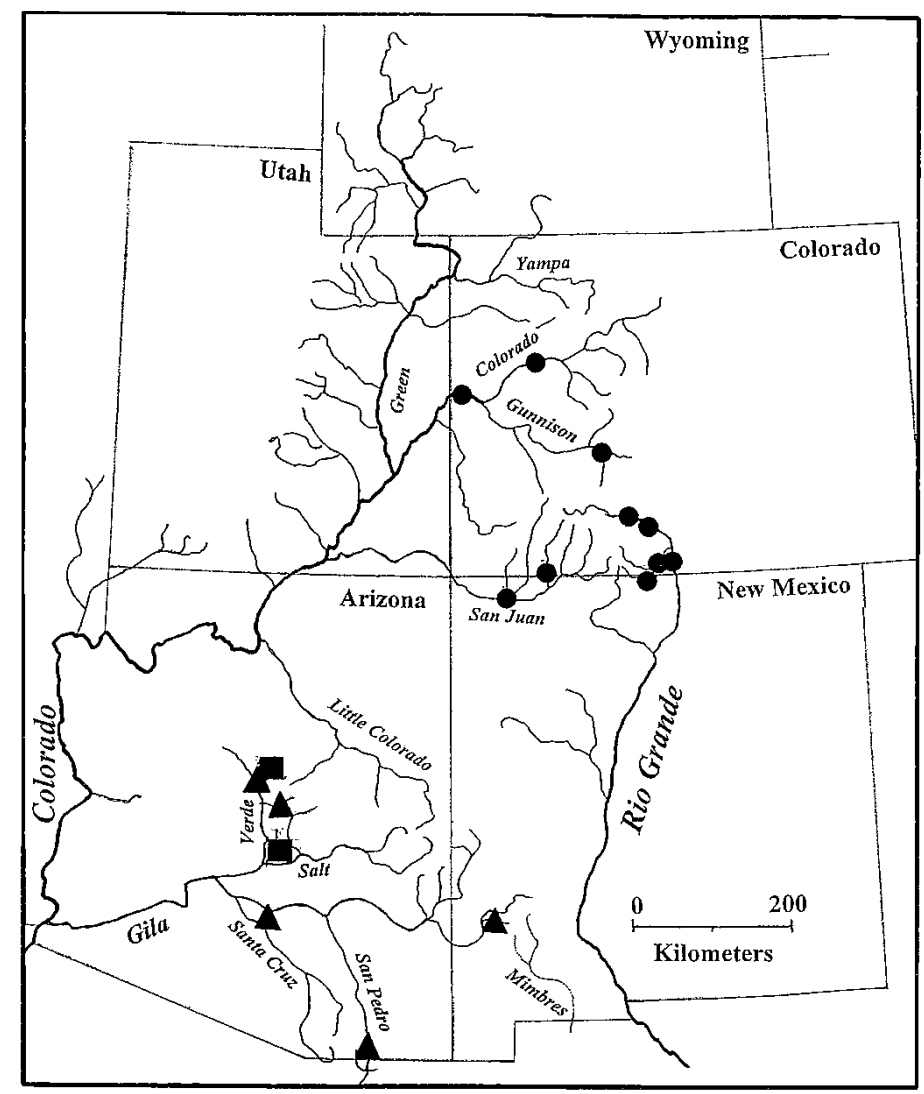

Fig. 1. Locations of limpets in Colorado, New Mexico, and Arizona. Circles represent Ferrissia rivularis in the upper Colorado, Gunnison, and San Juan drainages of the Colorado River and the Rio Grande drainage; triangles represent the Walker morph in the Gila River basin; squares represent the limpets from Wet Beaver Creek (Verde River) and Sycamore Creek sampled by the Arizona Department of Environmental Quality.

the Rio Grande to determine if this apex characteristic (the Walker morph) has a drainagedependent distribution or if it is a random shell morphology. The Gila River has been proposed as a southern paleoaquatic route for the exchange of eastern and western aquatic-dependent fauna between the Rio Grande basin, the Death Valley basin, and coastal drainages of California. As such, the presence of the Ferrissia in this drainage will expand the paleogeographical implications developed for fish (Minckley et al. 1986, Smith and Miller 1986, Crabtree and Buth 1987) and utilized for amphibians (Hovingh 1997), mollusks (Hershler and Liu 2008, Monk et al. 2010), and leeches (Hovingh et al. 2008).

After submitting this paper, I was privileged to preview the opus of Walther et al. (2010), who determined that the putative Ferrissia walkeri from Arkansas and Michigan was conspecific with Ferrissia fragilis. Hence, I herein refer to the Gila River population as the Walker morph in view of (1) the taxonomic revision of Ferrissia, (2) the strong shell structure characteristic that has been identified as Ferrissia walkeri, and (3) its river-basin-specific geographical distribution.

\section{Methods}

Limpets were found on the underside of stones and debris and occasionally on stems and the underside of leaves. The surveyed lentic and lotic sites numbered 77 in the Colorado River and 23 in the Gunnison River basins in Colorado; 35 in the San Juan River basin and 22 in the Rio Grande basin in Colorado and New Mexico; 110 in the Virgin River basin of Utah, Arizona, and Nevada; and 70 in the Little 
Colorado River basin and 158 in the Gila River basin of Arizona and New Mexico.

All limpet specimens were relaxed with menthol, fixed in $10 \%$ formalin in phosphatebuffered saline, placed in 70\% ethanol, and deposited in the mollusk collection of the Smithsonian Institution (USNM). The traditional morphometrics of length (l) and width (w) of the base, and height (h) from the base (aperture) to the apex (summit) were measured and standardized by the ratios w/l and h/l. The apex in Ferrissia rivularis is the protoconch or embryonic shell, while in F. walkeri the protoconch is posterior to and below the apex. The distance of the apex from the posterior margin (a) was measured, and its standardization (a/l) denotes the relative position of the apex on the dorsum. For instance, if a/l is 0.33 , the apex is one-third distant from the posterior margin and twothirds distant from the anterior margin. Measurements were determined by a calibrated grid in the eyepiece of a dissecting microscope set at one square per $\mathrm{mm}$ and with one square further subdivided into 0.2-mm squares. Measurements were estimated to $0.1 \mathrm{~mm}$.

Intermountain limpets were examined in museum collections from the Philadelphia Academy of Natural Science (ANSP), the California Academy of Sciences (CAS), the Chicago Field Museum of Natural History (FMNH), the Harvard Museum of Comparative Zoology (MCZ), the Los Angeles County Museum (LACM), the Santa Barbara Museum of Natural History (SBMNH), the University of Colorado Museum (UCM), the University of Michigan Museum of Zoology (UMMZ), the Utah Museum of Natural History (UU), and the Smithsonian Institution Museum of Natural History (USNM). Also examined were specimens from the collection of the Arizona Department of Environmental Quality.

\section{RESUlts}

Of the 495 sites surveyed in the Colorado River and Rio Grande drainage basins, limpets were only found in 16 locations (Fig. 1, Table 1). Limpets are often very localized within a stream and within a given reach. Limpets can be abundant under a single stone and sometimes under adjacent stones but rare elsewhere. In some streams, even with additional survey efforts, only a single individual is noted within a reach. The absence from most sites may represent in-stream

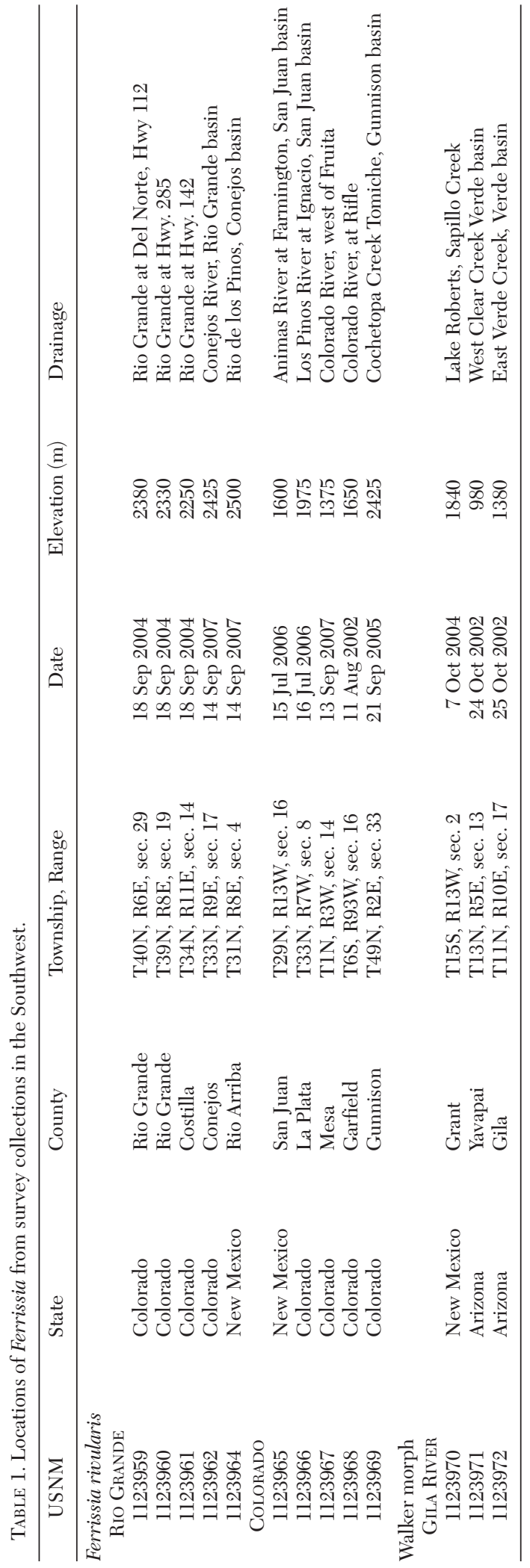


TABLE 2. Ferrissia shell morphometrics, standard deviations, and ranges (in parentheses): $l=$ length; $w=$ width; $h=$ height; a = length between posterior margin and maximum height. Bold highlights differences among and between populations of the Walker morph and F. rivularis. Yampa River is presented as an outlier to the region under study (see Hovingh 2004).

\begin{tabular}{|c|c|c|c|c|c|}
\hline & $n$ & $\begin{array}{c}\text { Length } \\
(\mathrm{mm})\end{array}$ & $\mathrm{w} / \mathrm{l}$ & $\mathrm{h} / \mathrm{l}$ & $\mathrm{a} / \mathrm{l}$ \\
\hline \multicolumn{6}{|l|}{ COLORADO RIVER BASIN } \\
\hline $\begin{array}{l}\text { Yampa River } \\
\text { (Green River basin,Colorado) }\end{array}$ & 65 & $\begin{array}{l}4.3 \pm 0.8 \\
(2.8-6.0)\end{array}$ & $\begin{array}{c}0.66 \pm 0.03 \\
(0.60-0.73)\end{array}$ & $\begin{array}{c}0.35 \pm 0.04 \\
(0.25-0.44)\end{array}$ & $\begin{array}{l}0.36 \pm 0.03 \\
(0.28-0.45)\end{array}$ \\
\hline \multicolumn{6}{|l|}{ UPPER COLORADO } \\
\hline $\begin{array}{l}\text { Colorado River, USNM } 1123967 \\
\text { (west of Fruita) }\end{array}$ & 6 & $\begin{array}{c}4.7 \pm 0.5 \\
4.0-5.6\end{array}$ & $\begin{array}{c}0.65 \pm 0.07 \\
0.50-0.67\end{array}$ & $\begin{array}{c}0.35 \pm 0.04 \\
(0.28-0.39)\end{array}$ & $\begin{array}{c}0.35 \pm 0.06 \\
(0.24-0.39)\end{array}$ \\
\hline $\begin{array}{l}\text { Gunnison River, USNM } 1123969 \\
\text { (Cochetopa Creek) }\end{array}$ & 17 & $\begin{array}{l}4.1 \pm 0.6 \\
(3.2-5.4)\end{array}$ & $\begin{array}{c}0.64 \pm 0.03 \\
(0.60-0.68)\end{array}$ & $\begin{array}{c}0.37 \pm 0.05 \\
(0.21-0.46)\end{array}$ & $\begin{array}{c}0.38 \pm 0.04 \\
(0.31-0.44)\end{array}$ \\
\hline $\begin{array}{l}\text { San Juan River, USNM } 1123966 \\
\text { (La Plata River) }\end{array}$ & 9 & $\begin{array}{l}4.8 \pm 1.1 \\
(2.4-6.6)\end{array}$ & $\begin{array}{c}0.67 \pm 0.02 \\
(0.62-0.70)\end{array}$ & $\begin{array}{l}0.40 \pm 0.04 \\
(0.32-0.44)\end{array}$ & $\begin{array}{l}0.39 \pm 0.05 \\
(0.35-0.50)\end{array}$ \\
\hline \multicolumn{6}{|l|}{ Rio Grande River Basin } \\
\hline $\begin{array}{l}\text { Rio Grande River, USNM } 1123961 \\
\quad \text { Colorado }\end{array}$ & 15 & $\begin{array}{l}3.9 \pm 0.6 \\
(2.6-5.4)\end{array}$ & $\begin{array}{l}0.59 \pm 0.05 \\
(0.48-0.63)\end{array}$ & $\begin{array}{c}0.37 \pm 0.03 \\
(0.32-0.42)\end{array}$ & $\begin{array}{l}0.40 \pm 0.04 \\
(0.32-0.49)\end{array}$ \\
\hline $\begin{array}{l}\text { Rio Grande, USNM } 1123964 \\
\quad \text { (Rio de los Pinos) }\end{array}$ & 12 & $\begin{array}{l}4.7 \pm 0.4 \\
(3.9-5.4)\end{array}$ & $\begin{array}{c}0.64 \pm 0.02 \\
(0.61-0.65)\end{array}$ & $\begin{array}{c}0.35 \pm 0.04 \\
(0.30-0.42)\end{array}$ & $\begin{array}{r}0.39 \pm 0.03 \\
(0.33-0.43)\end{array}$ \\
\hline \multicolumn{6}{|l|}{ GILA RIVER Basin } \\
\hline $\begin{array}{l}\text { Gila River, UU } 14230 \\
{\text { (San Pedro River })^{\mathrm{a}}}^{\text {Sa }}\end{array}$ & 13 & $\begin{array}{l}3.2 \pm 0.5 \\
(2.6-4.6)\end{array}$ & $\begin{array}{c}0.53 \pm 0.03 \\
(0.49-0.60)\end{array}$ & $\begin{array}{c}0.32 \pm 0.03 \\
(0.27-0.38)\end{array}$ & $\begin{array}{c}0.27 \pm 0.03 \\
(0.22-0.32)\end{array}$ \\
\hline $\begin{array}{l}\text { Gila River, USNM } 1123970 \\
\quad \text { (Lake Roberts) }\end{array}$ & 4 & $\begin{array}{l}3.1 \\
(3.0-3.2)\end{array}$ & $\begin{array}{l}0.61 \\
(0.60-0.69)\end{array}$ & $\begin{array}{l}0.27 \\
(0.27-0.28)\end{array}$ & $\begin{array}{l}0.28 \\
(0.27-0.31)\end{array}$ \\
\hline $\begin{array}{l}\text { Santa Cruz drainage } \\
\quad \text { Sabino Canyon FMNH } 64331\end{array}$ & 4 & $\begin{array}{l}3.3 \\
(3.0-3.8)\end{array}$ & $\begin{array}{l}0.59 \\
(0.53-0.62)\end{array}$ & $\begin{array}{l}0.31 \\
(0.29-0.33)\end{array}$ & $\begin{array}{l}0.22 \\
(0.19-0.28)\end{array}$ \\
\hline $\begin{array}{l}\text { Gila River, USNM } 1123971 \\
\text { (West Clear Creek, Verde River) }\end{array}$ & 5 & $\begin{array}{l}2.2 \\
(2.0-2.5)\end{array}$ & $\begin{array}{l}0.63 \\
(0.55-0.65)\end{array}$ & $\begin{array}{l}0.39 \\
(0.28-0.52)\end{array}$ & $\begin{array}{l}0.28 \\
(0.20-0.33)\end{array}$ \\
\hline $\begin{array}{l}\text { Gila River, USNM } 1123972 \\
\quad \text { (East Verde Creek) }\end{array}$ & 4 & $\begin{array}{l}2.1 \\
(1.8-2.3)\end{array}$ & $\begin{array}{l}0.66 \\
(0.65-0.70)\end{array}$ & $\begin{array}{l}0.35 \\
(0.33-0.43)\end{array}$ & $\begin{array}{l}0.28 \\
(0.25-0.33)\end{array}$ \\
\hline Ferrissia walkeri ANSP 87479a & 7 & $\begin{array}{l}4.0 \pm 0.5 \\
(3.6-5.1)\end{array}$ & $\begin{array}{c}0.64 \pm 0.02 \\
(0.61-0.66)\end{array}$ & $\begin{array}{c}0.26 \pm 0.02 \\
(0.23-0.29)\end{array}$ & $\begin{array}{c}0.30 \pm 0.03 \\
(0.24-0.32)\end{array}$ \\
\hline Ferrissia fragilis ANSP 22011 a & & 3.9 & 0.48 & 0.31 & 0.32 \\
\hline
\end{tabular}

aPresented in Hovingh (2004) and used here for comparisons.

habitat requirements, life-history-related time of year, and drainage history. Limpet site fidelity is shown by repeat collections in Gunnison, Rio Grande, and Costilla counties of Colorado at sites reported by Wu (1989), and in Sabino Canyon, Arizona, where Ferriss collected limpets in 1913 and where limpets are present today (Bequaert and Miller 1973; P. Hovingh personal observation).

The identification of Ferrissia, as described by Basch (1963), is largely based on shell morphology and habitat. Habitat is a poor taxonomic feature, as lentic and lotic environments have an intermediate continuum. Table 2 shows the morphometrics of the collected limpets. The characters $w / 1$ and $h / l$ are largely identical for all populations. Gila River specimens were shorter with average length $<3.3 \mathrm{~mm}$, as described for F. fragilis (Tryon 1863, Burch 1989), while the Colorado River and Rio Grande basins' specimens averaged $>3.9 \mathrm{~mm}$. Species length overlapped in the sampled rivers. The a/l metric distinguished the Gila River populations, with average values $<0.28$, while Ferrissia from the upper Colorado River and Rio Grande basins had average a/l values greater than 0.34 . These indicators also overlapped. All of the Gila River specimens were very fragile. Those collected for water quality analysis were small and broken. Those 2 characteristics-small and fragile-would nominally place the Gila River specimens into the F. fragilis group, although either characteristic could be environmentally determined.

Figure 2A illustrates the Walker morph from West Clear Creek (Verde River); Figure 2B, F. walkeri by Pilsbry and Ferriss (1907); and Figure 2C, F. rivularis from Cochetopa Creek 


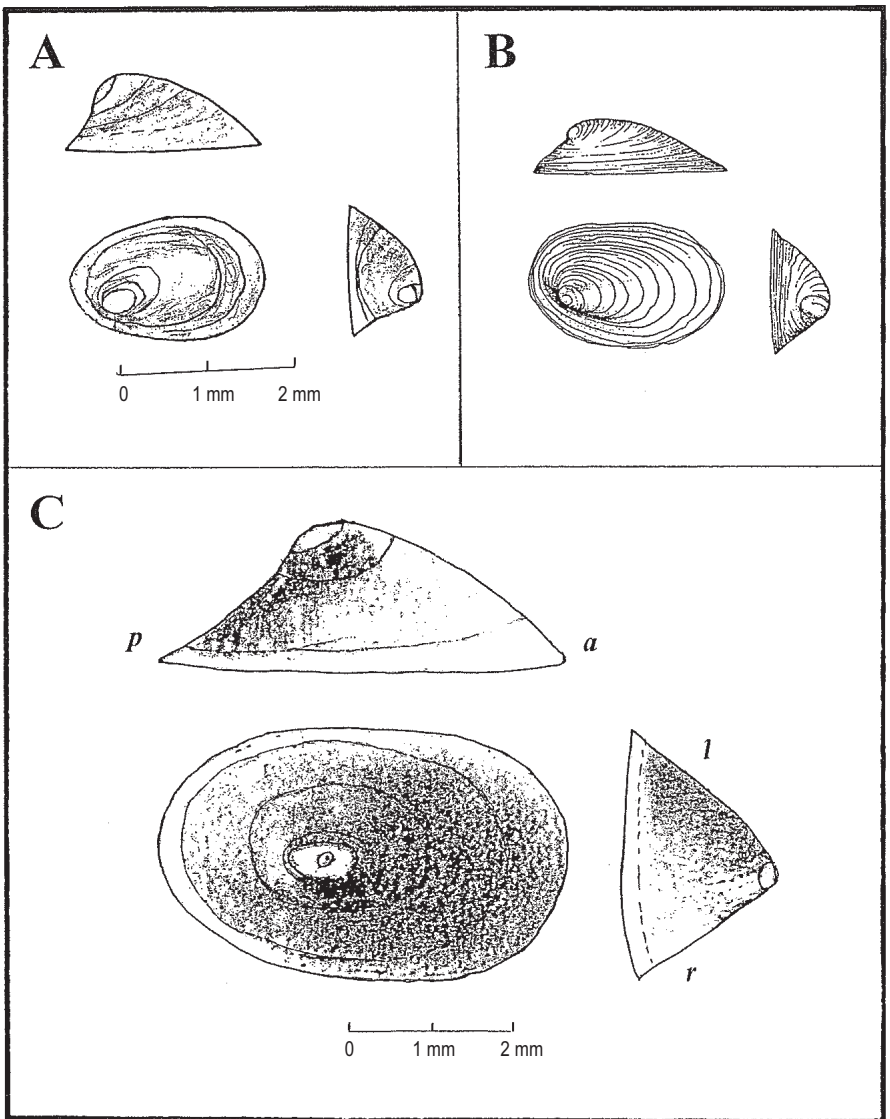

Fig. 2. Views of Ferrissia: A, Ferrissia walkeri from East Verde River, Gila River, Arizona; B, Ferrissia walkeri as shown in the species description by Pilsbry and Ferriss (1906); C, Ferrissia rivularis from the Cochetopa Creek, Gunnison River basin, Colorado. Each panel shows the top, right-side, and posterior views of the shell. Shell positions are denoted as $p$, posterior; $a$, anterior; $l$, left side; and $r$, right side.

(Gunnison River). The uniqueness of the $F$. walkeri shell is clearly shown, and as the initial description states, "the apex [is] depressed, radially striatae, situated behind the posterior third, and much nearer the right than the left margin." In addition, "the summit of the shell is in front of the somewhat depressed apex." The identification description is rather clear and distinguishes F. walkeri from other Ferrissia species. Figures $2 \mathrm{~A}$ and $2 \mathrm{~B}$ show the unmeasured uniqueness of the Ferrissia walkeri shell. The vertical trending protoconch ("apex" in Pilsbry and Ferriss 1907) lies well within the right posterior quadrant, and its anterior margin is lower than the height ("summit" in Pilsbry and Ferriss 1907). Thus, F. walkeri has been identified in streams and a lake (Lake Roberts Reservoir) in the Gila River basin by these criteria.
The shells of the Verde River population have greater height (h/l average 0.35-0.39), while the shells of the Lake Roberts (New Mexico) and Sabino Canyon (Santa Cruz basin) populations are more depressed with $\mathrm{h} / \mathrm{l}$ averages of 0.27 and 0.31 , respectively. Only F. rivularis occurred elsewhere in the Intermountain region (Hovingh 2004).

\section{Discussion}

In the introduction I referred to the Gila River Ferrissia as the Walker morph, based on the F. walkeri species description (Pilsbry and Ferriss 1907). The Arizona limpets were identified as F. fragilis (Bequaert and Miller 1973, Blinn et al. 1989), with the specimens from Sabino Canyon collected by Ferriss in 1913. 
Ferrissia fragilis is known to be highly variable (Basch 1963). The original description by Tryon (1863) characterizes this limpet as small and fragile, and "apex elevated acute, curved backwards, with about two-thirds of the shell anterior to it." This description could include the Gila River limpets, whereas most Ferrissia specimens have the apex central in the posterioranterior length axis or slightly to the right (Clarke 1981).

Species identification in the literature may hinge on a single trait: small, fragile, apex distance from the anterior, or habitat. Wu (1989) noted F. walkeri and F. rivularis cohabiting the same sites in the Yampa River drainage (Green River, Colorado River; Fig. 1) with the former being more depressed than the latter. Ferrissia fragilis was noted at one site in Colorado, Yuma County, Great Plains. The protoconch of this specimen was well within the right posterior quadrant, and the specimen had an a/l of 0.3 , similar to the profile of F. walkeri. Two other reports mentioned F. walkeri in the Great Plains (southern Oklahoma, Murray County, and north central Texas, Tarrant County) without identifying criteria (McMahon et al. 1976, McMahon and Hopkins 1977). Basch (1963) considered 2 populations (often listed as from California) described in 1924 from the same pool near San Jose del Cabo on the southern tip of Baja California Sur (Ferrissia bayacalifornica, USNM $264600 \mathrm{H}, 361554$, and Ferrissia occidentalis USNM $3615533 \mathrm{H}, 361555)$ with the vertical trending protochonch well within the posterior right quadrant as F. walkeri. Since the Gila River populations were identified as $F$. fragilis (= Laevapex californica) by Ferriss who first collected them in Sabino Canyon, the Walker morph is a variant of $F$. fragilis (Bequaert and Miller 1973). In this case, the Walker morph has a basin-wide distribution with no other morphs (e.g., with the apex located centrally on the anterior-posterior axis) of $F$. fragilis present.

The Gila River Ferrissia represents populations that are found in west coast and eastern United States drainages (Basch 1963, Taylor 1981), a pattern that in part mimics the distribution of the leech Mooreobdella microstoma (Hovingh et al. 2008). The Gila River has been suggested as a paleoaquatic drainage corridor for aquatic fauna between the eastern and western United States, either through northern Mexico or the upper Rio Grande basin (Minckley et al. 1986, Smith and Miller 1986).
Fish studies have suggested aquatic exchanges some 9 to $10 \mathrm{Ma}(\mathrm{Ma}=$ million years ago $)$ between the Rio Grande and Colorado River basins, 5.1 to $1.9 \mathrm{Ma}$ (depending on the fish species) between the Colorado River and Los Angeles basins, and more than 11 Ma between the Colorado River and Death Valley basins (Echelle 2008, Knott et al. 2008, Spencer et al. 2008). Monk et al. (2010) showed that the Gila River mussel Anodonta formed a clade with the southern coast and Grand Valley Anodonta of California but not with the Death Valley basin population. Hershler and Liu (2008), in their description of the complexity of Pyrgulopsis springsnail distribution in the Death Valley basin, noted that major events have happened in the basin at different times: the oldest vicariant event occurred prior to $6 \mathrm{Ma}$ between the Gila River and Death Valley before the Gila River joined the Colorado River. The presence of Ferrissia in Baja California Sur and in California could be explained by similar transfer events and with the 4-5.5 Ma rifting of the peninsula from the mainland and the complete formation of the Gulf of California by $3 \mathrm{Ma}$ (Grismer 1994). The absence of the Walker morph in the upper Rio Grande and the Little Colorado and San Juan rivers suggests that the Gila River population arrived by connections through northern Mexico and not through the upper Rio Grande.

\section{Conclusion}

Although the limpets discussed in this paper were named over 100 years ago, there is much confusion in the literature and museum collections about what defines a limpet species. With close attention to the original descriptions, Ferrissia walkeri was identified from 8 sites in the Gila River basin of Arizona and New Mexico by its invariable characteristic: the vertical trending protoconch well positioned in the posterior right quadrant, one-third distant from the posterior margin, and below the apex. Its shell shapes were variable and dependent upon local aquatic environments. Inasmuch as the species listed in Arizona is F. fragilis, a limpet with similar shell shape and size, I consider the species in the Gila River as Walker morph of $F$. fragilis until further work is done with the southwest and Mexican limpets. While this action certainly would alleviate some of the confusion in the literature, the morph description has its own importance. 


\section{ACKNOWLEDGMEnTS}

I thank the following museums for use of their facilities and access to their collections: the Academy of Natural Science in Philadelphia, the California Academy of Sciences, the Field Museum of Natural History, the Harvard Museum of Comparative Zoology, the Santa Barbara Museum of Natural History, the National Museum of Natural History at the Smithsonian Institution, the University of Colorado at Boulder, the University of Michigan Museum of Zoology, and the Utah Museum of Natural History. I am greatly indebted to P. Spindler for opportunities to examine the extensive collection from Arizona, to D. Ó Foighil for the opportunity to review a relevant paper on Ferrissia, and to R. Hershler and his interest in western aquatic fauna. I also thank the WNAN editorial staff for their suggestions for improving the text.

\section{Literature Cited}

BASCH, P.F. 1963. A review of the recent freshwater limpet snails of North America (Mollusca: Pulmonata). Bulletin of the Museum of Comparative Zoology 129: 401-461.

Bequaert, J.C., AND W.B. MilLer. 1973. The mollusks of the arid Southwest, with an Arizona check list. University of Arizona Press, Tucson, AZ.

Blinn, D.W., R.E. TruitT, and A. Pickart. 1989. Feeding ecology and radular morphology of the freshwater limpet Ferrissia fragilis. Journal of the North American Benthological Society 8:237-242.

BurCH, J.B. 1989. North American freshwater snails. Malacological Publications, Hamburg, MI.

Clarke, A.H. 1981. The freshwater molluscs of Canada. National Museum of Natural Sciences, Ottawa, Canada.

Crabtree, C.B., AND D.G. Buth. 1987. Biochemical systematics of the catostomid genus Catostomus: assessment of C. clarki, C. plebeius, and C. discobolus including the Zuni sucker C. d. yarrowi. Copeia 1987:843-854.

EchelLe, A.A. 2008. The western North American pupfish clade (Cyprinodontidae: Cyprinodon): mitochondrial DNA divergence and drainage history. Pages 27-38 in M.C. Reheis, R. Hershler, and D.M. Miller, editors, Late Cenozoic drainage history of the southwestern Great Basin and Lower Colorado River region: geologic and biotic perspectives. Geological Society of America Special Paper 439. doi:10.1130/2008.2439(02)

Grismer, L.L. 1994. The origin and evolution of the peninsular herpetofauna of Baja California, Mexico. Herpetological Natural History 2:51-106.

Hershler, R., AND H.-P. Liu. 2008. Ancient vicariance and recent dispersal of springsnails (Hydrobiidae: Pyrgulopsis) in the Death Valley system, California-Nevada. Pages 91-101 in M.C. Reheis, R. Hershler, and D.M. Miller, editors, Late Cenozoic drainage history of the southwestern Great Basin and Lower Colorado River region: geologic and biotic perspectives. Geological
Society of America Special Paper 439. doi:10.1130/ 2008.2439(04)

HovingH, P. 1997. Amphibians in the eastern Great Basin (Nevada and Utah, USA): a geographical study with paleozoological models and conservation implications. Herpetological Natural History 5:97-134.

2004. Intermountain freshwater mollusks, USA (Margaritifera, Anodonta, Gonidea, Valvata, Ferrissia): geography, conservation, and fish management implications. Monographs of the Western North American Naturalist 2:109-135.

Hovingh, P., W.H. Clark, and J. KeEbaugh. 2008. Leeches of the Snake River in Idaho and Oregon: paleodrainage implications of Mooreobdella microstoma. Western North American Naturalist 68:210-224.

Knott, J.R., M.N. Machette, R.E. Klinger, A.M. SarnaWojCiCKI, J.C. LIDDiCOAT, J.C. TINSLEY III, B.T. DAVID, AND V.M. EBBS. 2008. Reconstructing late Pliocene to middle Pleistocene Death Valley lakes and river systems as a test of pupfish (Cyprinodontidae) dispersal hypotheses. Pages 1-26 in M.C. Reheis, R. Hershler, and D.M. Miller, editors, Late Cenozoic drainage history of the southwestern Great Basin and Lower Colorado River region: geologic and biotic perspectives. Geological Society of America Special Paper 439. doi:10.1130/2008.2439(01)

McMahon, R.F., D.W. Aldridge, and G.L. King. 1976. New distribution records for two species of freshwater limpet (Pulmonata: Basommatophora) in southern Oklahoma. Southwestern Naturalist 21:241-242.

McMahon, R.F., AND A.W. Hopkins. 1977. New populations of the fresh-water limpets, Ferrissia walkeri (Pilsbry and Ferriss) and Laevapex fuscus (C.B. Adams) (Pulmonata: Ancylidae) in north-central Texas. Southwestern Naturalist 22:353-358.

MinCKLeY, W.L., D.A. HendRicKSON, AND C.E. Bond. 1986. Geography of western North American freshwater fishes: description and relationships to intracontinental tectonism. Pages 519-613 in C.H. Hocutt, and E.O. Wiley, editors, The zoogeography of North American freshwater fishes. John Wiley \& Sons, Inc., New York, NY.

Monk, K.E., J.C. Brimbox, J.P. Chong, J.K. Howard, D.A NeZ, D. Wolf, and R.S. Gardner. 2010. Genetic structuring in the freshwater mussel Anodonta corresponds with major hydrologic basins in the western United States. Molecular Ecology 19:557-568.

NEWTON, I. 2003. The speciation and biogeography of birds. Academic Press, London, England.

Pilsbri, H.A., AND J.H. Ferriss. 1907. Mollusca of the Ozarkian fauna. Proceedings of the Academy of Natural Sciences of Philadelphia 58:529-567.

SAY, T. 1817. Accounts of two new genera and several new species of fresh water and land snails. Journal of the Academy of Natural Sciences [Philadelphia] 1:123126.

SMith, M.L., AND R.R. Miller. 1986. The evolution of the Rio Grande Basin as inferred from its fish fauna. Pages 175-234 in C.H. Hocutt, and E.O. Wiley, editors, The zoogeography of North American freshwater fishes. John Wiley \& Sons, Inc., New York, NY.

Spencer, J.E., G.R. SMith, AND T.E. Dowling. 2008. Middle to late Cenozoic geology, hydrography, and fish evolution in the American Southwest. Pages 279-299 in M.C. Reheis, R. Hershler, and D.M. Miller, editors, Late Cenozoic drainage history of the southwestern Great Basin and Lower Colorado River region: 
geologic and biotic perspectives. Geological Society of America Special Paper 439. doi:10.1130/2008 $.2439(12)$

TAYLOR, D.W. 1981. Freshwater mollusks of California: a distributional checklist. California Fish and Game 67:140-163.

Tryon, G.W. 1863. Descriptions of new species of fresh water Mollusca, belonging to the families Amnicolidae, Valvatidae and Limnaeidae inhabiting California. Proceedings of the Academy of Natural Sciences of Philadelphia 3:147-150

Walther, A.C., J.B. Burch, and D. Ó Foighil. 2010. Molecular phylogenetic revision of the freshwater limpet genus Ferrissia (Planorbidae: Ancylinae) in North America yields two species: Ferrissia (Ferrissia) rivularis and Ferrissia (Kincaidilla) fragilis. Malacologia 53:25-46.

WU, S.-K. 1989. Colorado freshwater mollusks. Natural History Inventory of Colorado No. 11, University of Colorado Museum, Boulder, CO.

Received 30 March 2009 Accepted 27 May 2010 